\title{
Iraq healthcare system: The first year of covid-19 pandemic
}

Aamir Jalal Al-Mosawi

Advisor doctor and expert trainer, Baghdad Medical City and Iraqi Ministry of Health, Baghdad, Iraq.

*Corresponding Author: Aamir Jalal Al-Mosawi, Advisor doctor and expert trainer, Baghdad Medical City and Iraqi Ministry of Health, Baghdad, Iraq.

Received Date: 06 August 2021 | Accepted Date: 10 September 2021 | Published Date: 17 September 2021

Citation: Aamir Jalal Al-Mosawi. (2021) Iraq healthcare system: The first year of covid-19 pandemic. J.Clinical and Laboratory Research. 3(4); DOI: $10.31579 / 2768-0487 / 042$

Copyright: (C) 2021 Aamir Jalal Al-Mosawi. This is an open-access article distributed under the terms of the Creative Commons Attribution License, which permits unrestricted use, distribution, and reproduction in any medium, provided the original author and source are credited.

\section{Abstract}

Background: The year 2020 witnessed the rapid spread of covid-19 pandemic in Iraq and in almost all the countries in the world. This spread has created a serious health crises and a public health emergency in Iraq and throughout the world. Throughout the world, healthcare systems have been negatively influenced by the pandemic and experienced unexpected changes. We have previously provided several descriptions of the Iraq health care system from its evolution. However, little is known about the health care system in Iraq during the first year of the coves pandemic. The aim of this paper is provide a description of the healthcare system in Iraq during the year 2020, the first year of covid-19 global pandemic.

Materials and methods: The available unpublished and published data about the Iraqi healthcare system during the first year of covid-19 pandemic, the year 2020 were examined. The data included more than 100 relevant unpublished and published information documents including journal articles, books, official reports of the Iraqi Ministry of Planning and Iraqi Ministry of Health. In addition, relevant useful data available at internet web sites were also reviewed. The available relevant data were classified into categories including; demographic data relevant to healthcare, Data related to covid-19 disease in Iraq, data related to the organizational structure of the healthcare system, data related to national healthcare policies including national healthcare mission, vision, strategic goals and plans, data related to healthcare system financing, data about healthcare services delivery, data about the workforce in the Iraq healthcare system, data related to child health and maternal, data about notifiable infectious disease, data about chronic disorders and the main causes of morbidity and mortality, and data about medical education and healthcare education. Many relevant healthcare data for three provinces (The Kurdish provinces in the north of Iraq) of the eighteen provinces in Iraq were not available in English or Arabic.

Results: The population of Iraq in 2020 was estimated at 40.150 .174 (20.284.823 males and 19.865.351 females). During the year 2020, 595291 cases of covid-19 disease were registered by the Iraqi Ministry of Health. 12813 (2.15\%) patients died and 537841 $(90.3 \%)$ patients experienced recovery. The organizational structure of the Iraq health system, the backbone of the Iraq healthcare system witnessed no important change from the description before covid-19 global pandemic in 2019.

The declared mission and vision of the Iraqi Ministry of Health for the year 2020 were the same mission and vision of the Iraqi Ministry of Health that were declared in 2018. In 2020, the Iraqi Ministry of Health declared a strategic plan which included a vision and mission statements for the health information system. The first year of covid-19 pandemic in Iraq was not associated with an important increase in the number of primary healthcare centers. However, there was little increase in the number of governmental hospitals. Surprisingly, the bed occupancy rate of governmental hospitals during the first year of the pandemic was lower than the bed occupancy rate during the two years before the pandemic. The total number of hospitalized patients in 2020 was lower than the previous four years, but the mortality rate per 1000 hospitalized patients was significantly higher in 2020 than the previous four years.

Conclusion: Covid-19 disease in Iraq was associated with a significant mortality during the year 2020. It actually changed the previously reported national mortality pattern as covid-19 has become the second most common cause of death in Iraq. Contradictory, to the general belief that mortality associated with covid-19 disease was generally restricted to the older age groups, 117 children under the age of ten years died because of covid-19 disease in 2020. This number of childhood deaths suggests the need to consider vaccination of the younger age groups and to perform the relevant research. Covid-19 disease has emerged as a new notifiable infectious disease in Iraq and throughout the world; therefore, it changed the pattern of notifiable infectious diseases in Iraq.

Keywords: healthcare system; iraq; covid-19 pandemic; mortality 


\section{Introduction}

There are four genera of coronaviruses including alpha-coronaviruses, beta-coronaviruses, gamma-coronaviruses, and delta -coronaviruses. Alpha and beta-coronavirus can infect mammals, while gammacoronavirus and delta-coronavirus generally infect birds. Four coronaviruses are known to cause mild upper respiratory infection in humans of all ages including infants.

The transmission of coronaviruses from animals (birds) to causes respiratory illness has been reported as early as 1969 by Kapikian et al. Community-wide outbreak associated with 229E-like coronavirus has be reported as early as 1970 by Cavallaro and Monto. Until December, 2020, two beta-coronaviruses (SARS coronaviruses and MERS-coronaviruses were known to cause severe, potentially fatal pneumonia-like illness [1$6]$.

Errors in the replication of viral genomic RNA of zoonotic coronaviruses led to the emergence of genetically related diverse quasi-species, while the transmission of some of them to a new host species led to the emergence of human severe acute respiratory syndrome coronavirus (SARS-CoV) and Middle East respiratory syndrome coronavirus (MERS$\mathrm{CoV})$. SARS-CoV emerged for the first time in Guangdong China in 2002 spread rapidly to many other counties causing more than 8000 cases with about $10 \%$ mortality. In 2012, it was thought that MERS-CoV was transmitted to humans from bats through an intermediate camel host leading to 1700 cases in 27 countries with about $40 \%$ mortality [1-4].

Increasing number of cases of severe potentially fatal pneumonia caused by a new $\beta$-coronavirus was reported from Wuhan China in December 2019 , and human-to-human transmission was confirmed early. On the $12^{\text {th }}$ of January, 2020 the World Health Organization (WHO) officially named the condition coronavirus disease 2019 (covid-19). The Coronavirus Study Group of the International Committee suggested naming the new coronavirus "SARS-CoV-2" [1-4].

The year 2020 witnessed the rapid spread of covid-19 pandemic in Iraq and in almost all the countries in the world. This spread has created a serious health crises and a public health emergency in Iraq and throughout the world.

Throughout the world, healthcare systems have been negatively influenced by the pandemic and experienced unexpected changes.

We have previously provided several descriptions of the Iraq health care system from its evolution. However, little is known about the health care system in Iraq during the first year of the coves pandemic.
The aim of this paper is provide a description of the healthcare system in Iraq during the year 2020, the first year of covid-19 global pandemic.

\section{Materials and methods}

The available unpublished and published data about the Iraqi healthcare system during the first year of covid-19 pandemic, the year 2020 were examined. The data included more than 100 relevant unpublished and published information documents including journal articles, books, official reports of the Iraqi Ministry of Planning and Iraqi Ministry of Health. In addition, relevant useful data available at internet web sites were also reviewed.

\section{The available relevant data were classified into categories including:}

Demographic data relevant to healthcare.

Data related to covid-19 disease in Iraq.

Data related to the organizational structure of the healthcare system.

Data related to national healthcare policies including national healthcare mission, vision, strategic goals and plans.

Data related to healthcare system financing.

Data about healthcare services delivery.

Data about the workforce in the Iraq healthcare system.

Data related to maternal and child health.

Data about notifiable infectious disease.

Data about chronic disorders and main causes of morbidity and mortality.

Data about medical education and healthcare education.

Many relevant healthcare data for three provinces (The Kurdish provinces in the north of Iraq) of the eighteen provinces in Iraq were not available in English or Arabic.

\section{Results}

\section{Demographic Data Relevant to Healthcare}

The population of Iraq in 2020 was estimated at 40.150 .174 (20.284.823 males and 19.865.351 females, with 102 males for each 100 females).

$40.5 \%$ of the population was under the age of fifteen years, and $5 \%$ above the age of 60 years. Figure- 1 shows the age distribution of Iraq population during the year 2020.69.8\% of the population was living in urban areas and $30.2 \%$ were of the living in rural areas. 


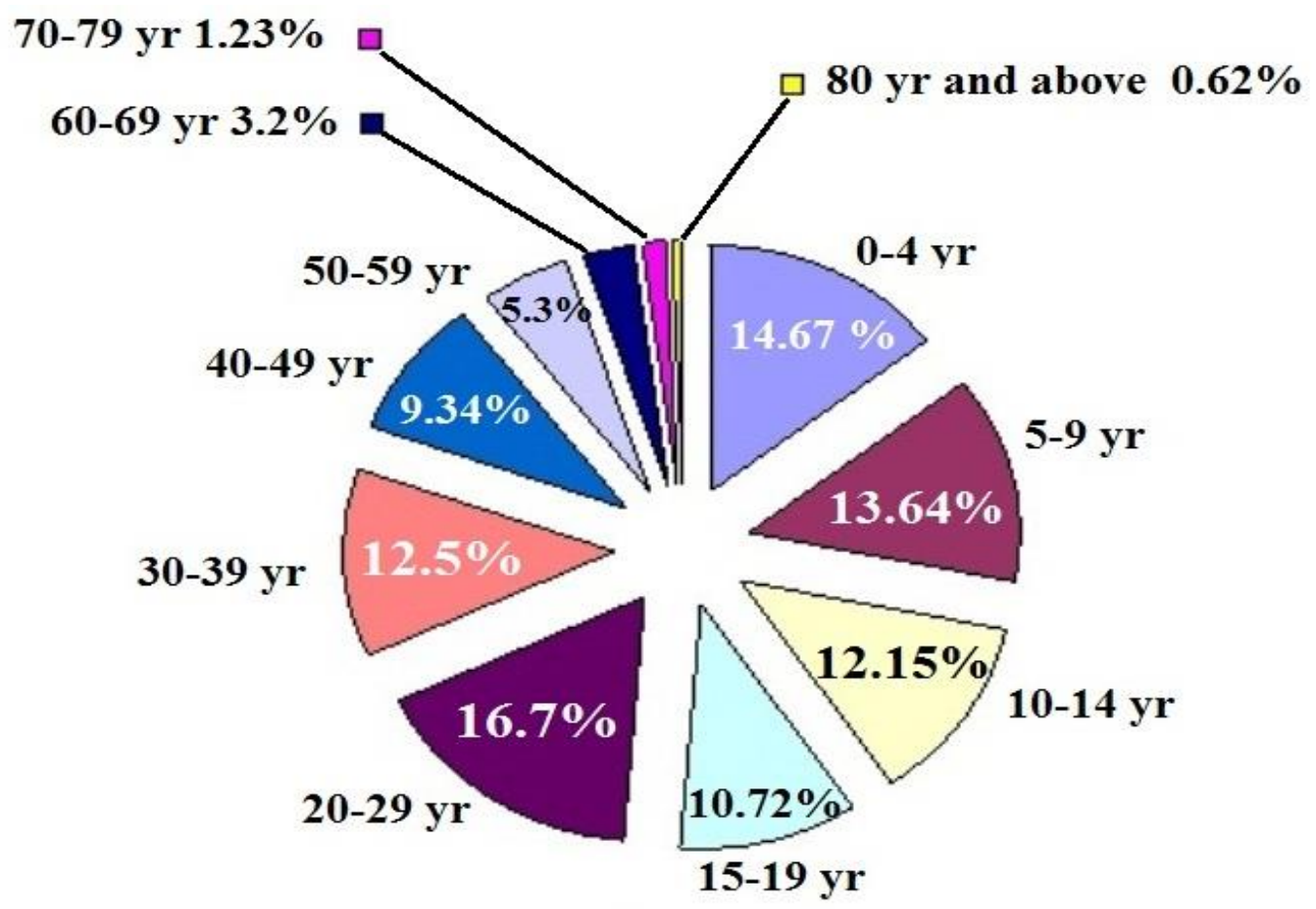

Figure 1: The age distribution of Iraq population during the year 2020

\section{Data Related To Covid-19 Disease in Iraq}

During the year 2020, 595291 cases of covid-19 disease were registered by the local and national health authorities, $12813(2.15 \%)$ patients died and $537841(90.3 \%)$ patients experienced recovery. 256 patients who died from covid-19 disease were affiliated to the Iraqi Ministry of Health including 56 medical personnel and 133 health personnel.

The spread of covid-19 disease in Iraq was first recognized during February, 2020 with the report of the first confirmed cases of the infections on the $22^{\text {nd }}$ of February in the province of Najaf.

The first reported case in Iraq was an Iranian student of religion. The first case of covid-19 in the Kurdish region of Iraq in the North of the country was reported on the first of March, 2020. However, the first death from covid-19 disease in Iraq was reported from the province of Suleimaniya in the Kurdish region of Iraq. The patient was a 70-year-old man who was known to have chronic heart failure associated with asthmatic manifestations.

The second death from covid-19 diseases in Iraq was reported from the province of Baghdad, while the first recovery was reported on the $6^{\text {th }}$ of March.

On the $27^{\text {th }}$ of March, 2020, all 19 Iraqi provinces have reported confirmed cases, and on the $7^{\text {th }}$ of April, 28,414 tests have been performed with 1202 of them were positive.

On the first of April, 2020, the total number of confirmed covid-19 disease cases in Iraq was 728. Early during June, the number of the reported cases exceeded 12,000, and the deaths exceeded 300. Table-1 shows the confirmed cases of covid-19 disease in the provinces of Iraq on the 7th of June 2020.

On the $28^{\text {th }}$ of June, the Iraqi Medical association reported occurrence of 45402 cases of covid-19 diseases including 788 Iraqi doctors, and 1756 patients died and including 13 Iraqi doctors.
People whom were considered to be healthy and possibly having good immunity like former football players and bodybuilding champions (Figure-2A) also died during the year 2020.

\begin{tabular}{||c|c|c|c||}
\hline Province & Cases & Deaths & Recovered \\
\hline Baghdad & 2,234 & 97 & 941 \\
\hline Al-Anbar & 6 & 0 & 5 \\
\hline Al-Qadisiyia & 15 & 1 & 11 \\
\hline Babil & 49 & 5 & 39 \\
\hline Basra & 747 & 18 & 578 \\
\hline Thi Qar & 96 & 4 & 72 \\
\hline Diyala & 45 & 5 & 21 \\
\hline Duhok & 102 & 0 & 26 \\
\hline Erbil & 397 & 4 & 243 \\
\hline Halabja & 25 & 0 & 22 \\
\hline Kerbala & 152 & 8 & 118 \\
\hline Kirkuk & 72 & 2 & 59 \\
\hline Maysan & 52 & 2 & 45 \\
\hline Muthanna & 117 & 4 & 95 \\
\hline Najaf & 431 & 6 & 324 \\
\hline Nineveh & 12 & 0 & 6 \\
\hline Suleimaniya & 811 & 23 & 246 \\
\hline Saladin & 127 & 0 & 18 \\
\hline Wasit & 1,018 & 18 & 139 \\
\hline Total & $\mathbf{1 2 , 3 6 6}$ & $\mathbf{3 4 6}$ & $\mathbf{5 , 1 6 8}$ \\
\hline \hline
\end{tabular}

Table 1: The confirmed cases of covid-19 disease in Iraq in the provinces of Iraq the 7th of June 2020. 


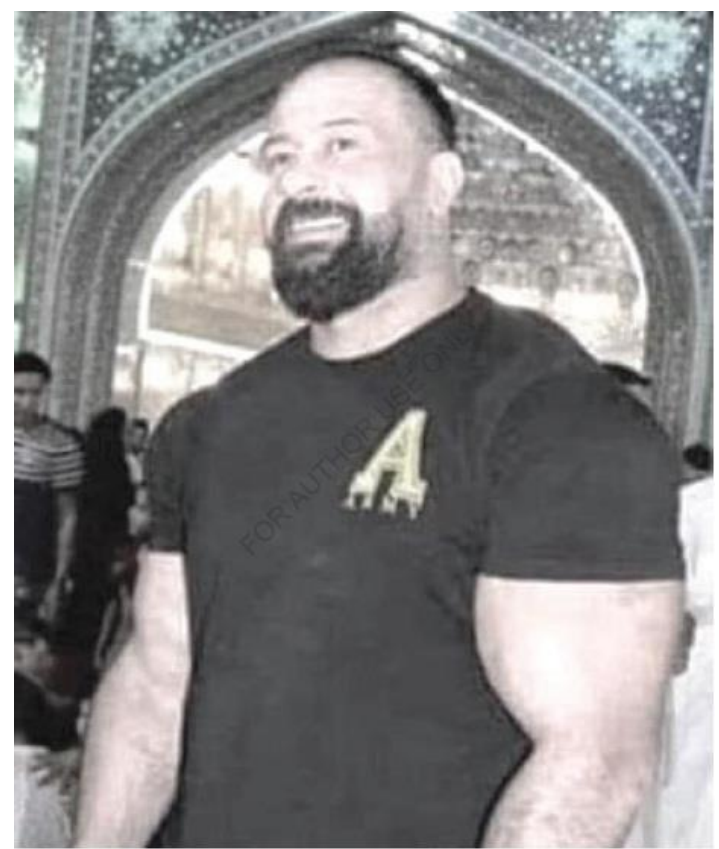

Figure 2A: Mohammed Al-Kaabi, an Iraqi bodybuilding champion who died because of covid-19 disease during the year 2020
The death of Ahmed Radhi (Figure-2B), a former player of the Iraqi National football team during June 2020 was associated with public criticism for the Iraqi Minister of Health during that time who was regarded as a non-technocrat minister as he was a military pharmacist and nor a real physician. Shortly after the death of Ahmed Radhi, Haider AlMulla , a politician asked the prime minister to appoint a real Minister of Health.

It is worth mentioning that Hassan Mohammed Abbas, the minister of health during that time was forced to resign during the year 2021 following the occurrence of a huge fire in Ibin Al-Khateeb Hospital in Baghdad and killed many patients.

In Iraq, a high covid-19 disease ministerial committee was established by the Iraqi Ministry of health to lead the efforts to control. The committee designed an official protocol (Figure-3) for the treatment of the disease and distributed it to hospitals.

Lopinavir/ritonavir + ribavirin combination was at the top of the suggested therapies to be used in the treatment of covid-19 disease, and that was excellent from the evidence-based medicine point of view. However, the suggested treatment was not available at all in the country. The second suggested treatment was plasma therapy which was impossible to offer to any patient needs treatment supposing that it is an acceptable therapeutic option.

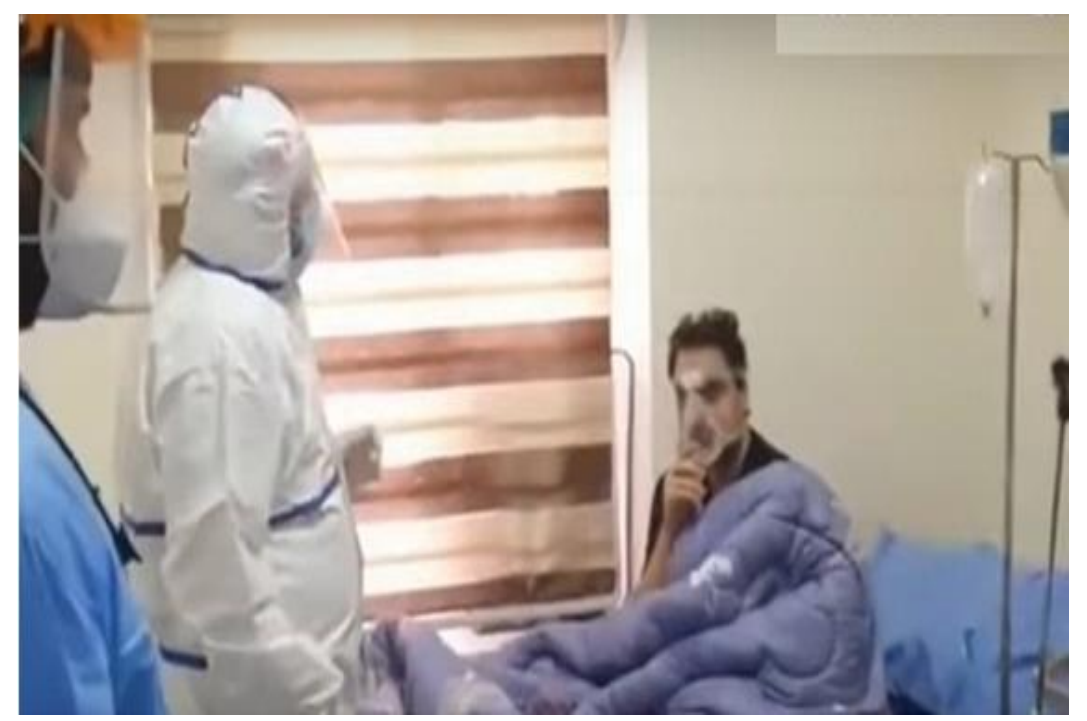

Figure 2B: Ahmed Radhi in hospital before his death. He was a former player of the Iraqi National football team who died during June, 2020, and his death was associate with public criticism for the Iraqi Minister of Health. 


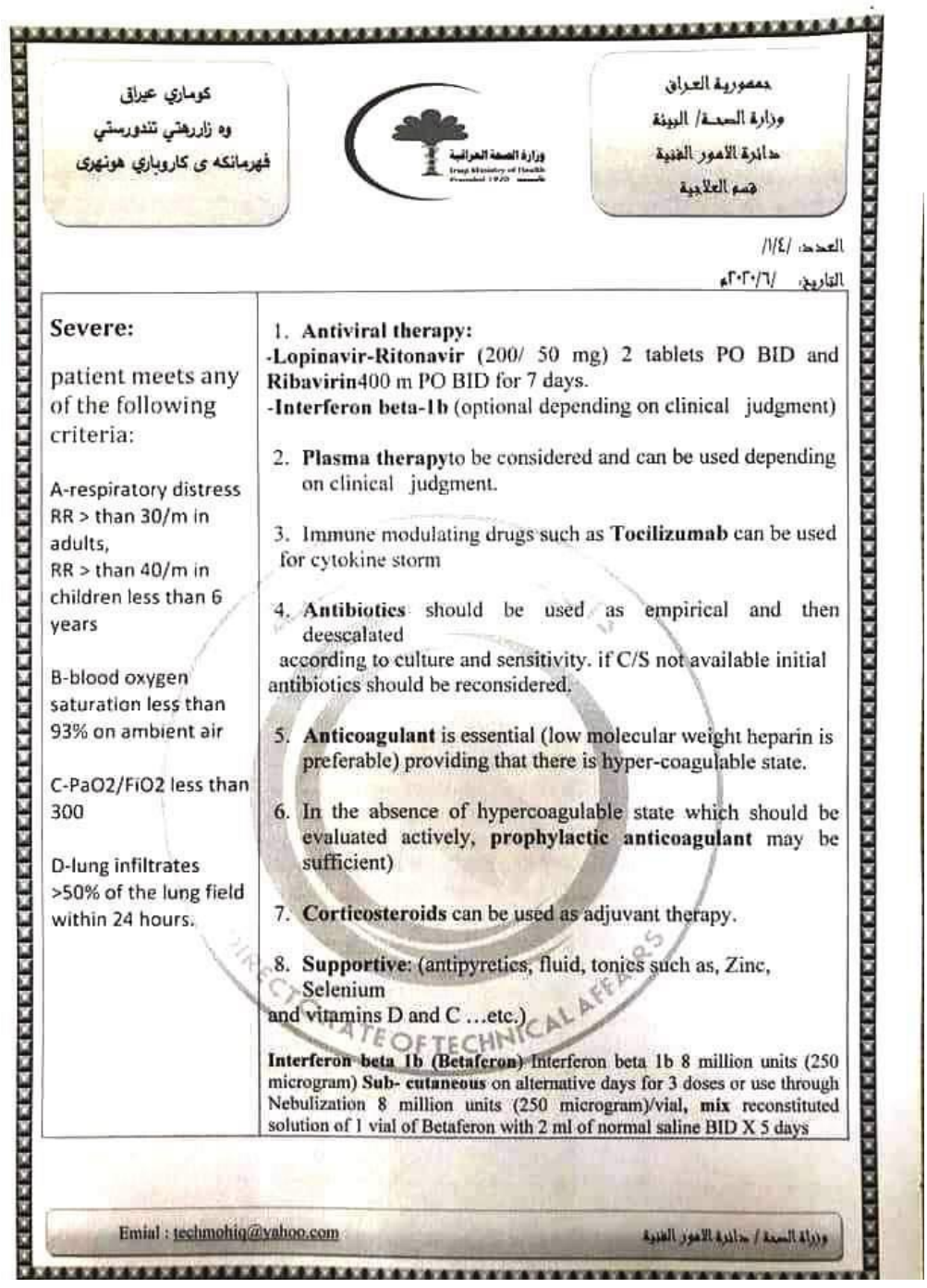

Figure 3: The official protocol designed by the higher ministerial committee for the treatment of covid-19 disease

During the year 2020, 182607 cases of covid-19 disease were registered in Baghdad accounting for $31 \%$ of the total cases of the disease in Iraq. Table-2 shows the number of covid-19 disease cases in the Iraqi provinces during the year 2020 and their outcomes of death or recovery.

$7680(1.4 \%)$ of the covid-19 disease in Iraq during the year 2020 were under the age of ten years, and therefore this age group was the least to be affected with covid-19 disease in this study. 133176 (23.9\%) of the covid19 disease in Iraq during the year 2020 aged between 30 and 39 years, and therefore this age group was the most affected with covid-19. Figure4 shows the age distribution of covid-19 patients during the year 2020 . Table- 3 shows the percentage of the recovered patients in various age groups.

\begin{tabular}{||c|c|c|c||}
\hline \hline Province & Cases & Deaths & Recovered \\
\hline Baghdad & 182607 & 2843 & 173186 \\
\hline Al-Anbar & 7739 & 71 & 7486 \\
\hline Al-Muthanna & 12501 & 231 & 11779 \\
\hline Al-Qadisiyia & 18352 & 407 & 17678 \\
\hline Babil & 20795 & 592 & 19882 \\
\hline Basra & 39835 & 915 & 38967 \\
\hline Thi Qar & 23808 & 813 & 22443 \\
\hline Diyala & 21413 & 273 & 20889 \\
\hline Duhok & 33932 & 681 & 23075 \\
\hline Erbil & 35717 & 912 & 25771 \\
\hline Kerbala & 22594 & 513 & 21486 \\
\hline Kirkuk & 31521 & 784 & 26824 \\
\hline \hline
\end{tabular}




\begin{tabular}{||c|c|c|c||}
\hline Maysan & 18435 & 445 & 17695 \\
\hline Najaf & 22025 & 318 & 21484 \\
\hline Nineveh & 23762 & 490 & 22184 \\
\hline Saladin & 15478 & 253 & 12321 \\
\hline Suleimaniya & 32741 & 1797 & 23027 \\
\hline Wasit & 32036 & 475 & 31664 \\
\hline Total & $\mathbf{5 9 5 2 9 1}$ & $\mathbf{1 2 8 1 3}$ & $\mathbf{5 3 7 8 4 1}$ \\
\hline
\end{tabular}

Table 2: The number of covid-19 cases in the Iraqi provinces during the year 2020.

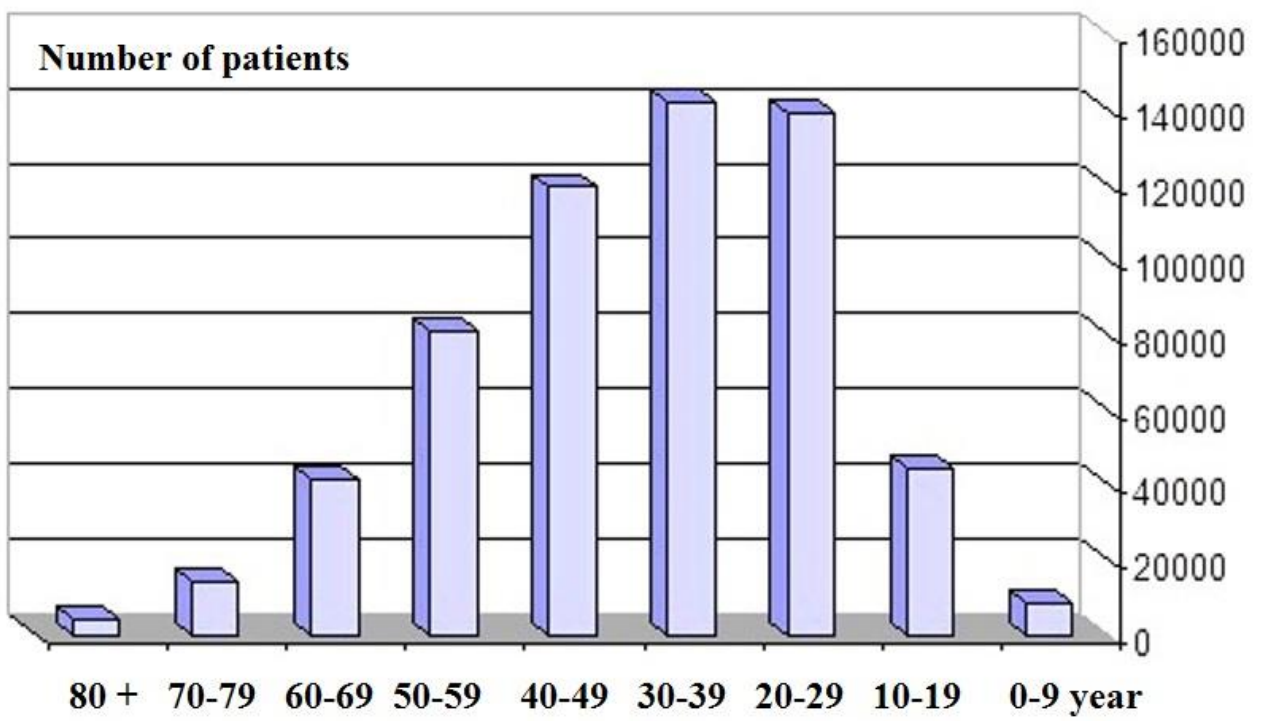

Figure 4: The age distribution of covid-19 patients during the year 2012.

\begin{tabular}{|c|c|}
\hline Age group & Percentage the recovered patients \\
\hline 0-9 year & $90.65 \%$ \\
\hline $10-19$ year & $90.45 \%$ \\
\hline $20-29$ year & $93.3 \%$ \\
\hline $30-39$ year & $93.56 \%$ \\
\hline $40-49$ year & $87.32 \%$ \\
\hline $50-59$ year & $90 \%$ \\
\hline $60-69$ year & $84 \%$ \\
\hline $70-79$ year & $80.26 \%$ \\
\hline 80 and older & $70 \%$ \\
\hline
\end{tabular}

Table 3: The percentage of the recovered patients in various age groups.

During the year 2020, 173928 individuals died in Iraq including 12813 deaths because of covid-19 disease which accounted for $7.36 \%$ of the total deaths in Iraq during the year 2020. Covid-19 resulted in a death rate of 33/ 100000 population in Iraq during the year 2020.

$117(0.9 \%)$ of the patients who died because of covid-19 disease in Iraq during the year 2020 were under the age of ten years, and therefore patients in this age group are the least likely to die from covid-19 disease.
$2418(18.9 \%)$ of the patients who died because of covid-19 disease aged 50 to 59 years.

Therefore, according to this study, patients in this age group are the most likely to die from covid-19 disease. Figure-5A shows the number of deaths in various age groups, and figure-5B shows the percentage of deaths in various age groups. 


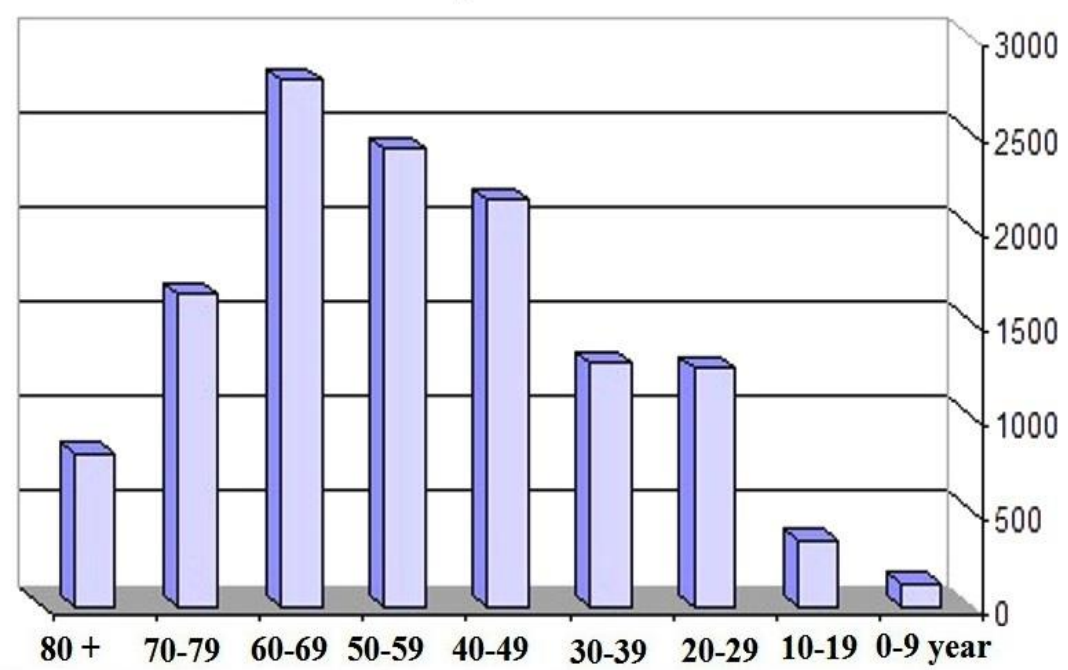

Figure 5A: The number of deaths in various age groups

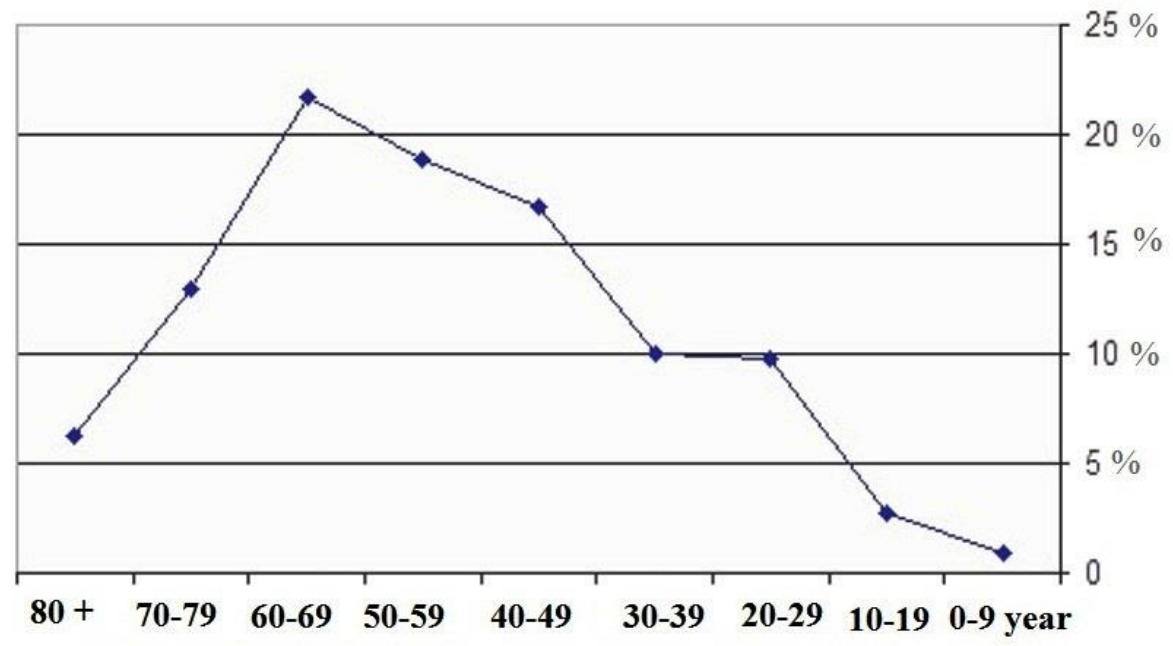

Figure 5B: The percentage of deaths in various age groups

Covid-19 disease was the second most common cause of death in Iraq accounting for $7.36 \%$ of all deaths in 2020 . Covid-19 disease was also the second most common cause of death in males, but it was the sixth most common cause of death in females. However, covid-19 disease was the third most common direct cause of maternal death.

Covid-19 disease was the sixth most common cause of hospitalization of patients aged 20 to 24 years in Iraq except the Kurdish provinces in the North of Iraq during the year 2020 accounting for $0.95 \%$.

\section{Data Related to the Organizational Structure of the Healthcare System}

The organizational structure of the Iraq health system, the backbone of the Iraq healthcare system witnessed no important change from the description before covid-19 global pandemic in 2019 [7,8,9,10].

Data Related To National Healthcare Policies Including National Healthcare Mission, Vision, Strategic Goals and Plans
Many of the national health policies declared by the Iraqi Ministry of Health have been included in articles $30,31,32$, and 33 of the constitution and witnessed no change [1, 2, 3, 4]. However, the year 2019 witnessed increasing public criticisms for the whole constitution of the country and serious demands for writing a new constitution $[7,8,9,10]$.

The declared mission and vision of the Iraqi Ministry of Health for the year 2020 were the same mission and vision of the Iraqi Ministry of Health which were declared in 2018.

The Mission stated "The Ministry of Health works to provide comprehensive health care to all members of the society and at the highest level of quality and to invest efficiently available resources in accordance with ethics of the profession and values of the society to ensure sustainable health development to reduce mortality and morbidly with participation of stakeholders". The general vision statement "Physically, psychologically, and socially healthy society". [7, 8, 9, 10].

In 2020, the Iraqi Ministry of Health declared a strategic plan which included a vision and mission statements for the health information 
system. The vision statement was "Comprehensive, efficient and applicable health information system".

The mission statement was "The Iraqi Ministry of Health works to provide the infrastructure and logistic supplies to build a statistical information base and an integrated sustainable health information system to insure access to health information by decision makers, policy makers, and researchers in the field of health to improve the comprehensive coverage, quality and efficiency of healthcare with highest quality".

\section{Data Related to Healthcare System Financing}

The Iraqi Ministry of Health remained largely funded centrally by the government. The total governmental budget allocation for the Iraqi Ministry of Health (excluding the budget of the Ministry of Health in Kurdistan) was reduced from 6,082,442,913,943 Iraqi Dinnars.

\section{Data about Healthcare Services Delivery}

The health services are delivered through hospitals, primary health centers and public health clinics [[7, 8, 9, 10].

The number of primary health centers in Iraq in 2020 was 2805 including $1192(42.5 \%)$ centers managed by physicians and $1613(57.5 \%)$.
Therefore, each primary health center has to provide health services for a population of 14314 , and there were 7 primary health centers for each 100,000 population.

There were 239 specialized centers in Iraq including 55 specialized dental centers, 21 specialized centers for respiratory diseases, and 8 asthma and allergy specialized centers.

There were 341public clinics in Iraq in 2020.

BCG vaccine was received by $98 \%$ of the target population, the third shot of poliomyelitis vaccine was received by $78 \%$ of the target population, $76 \%$ of measles vaccine target population received the vaccine.

In 2020, there were 295 governmental hospitals including specialized centers with inpatients, and 155 private hospitals. Figure- 6 shows the main types of governmental hospitals in Iraq in 2020.

Governmental hospitals included 49836 beds. Governmental hospitals beds' occupancy rate was $54.4 \%$. It was estimated that there was 1.2 hospital beds for each 1000 population.

A total of 1883 premature neonates' incubators were available.

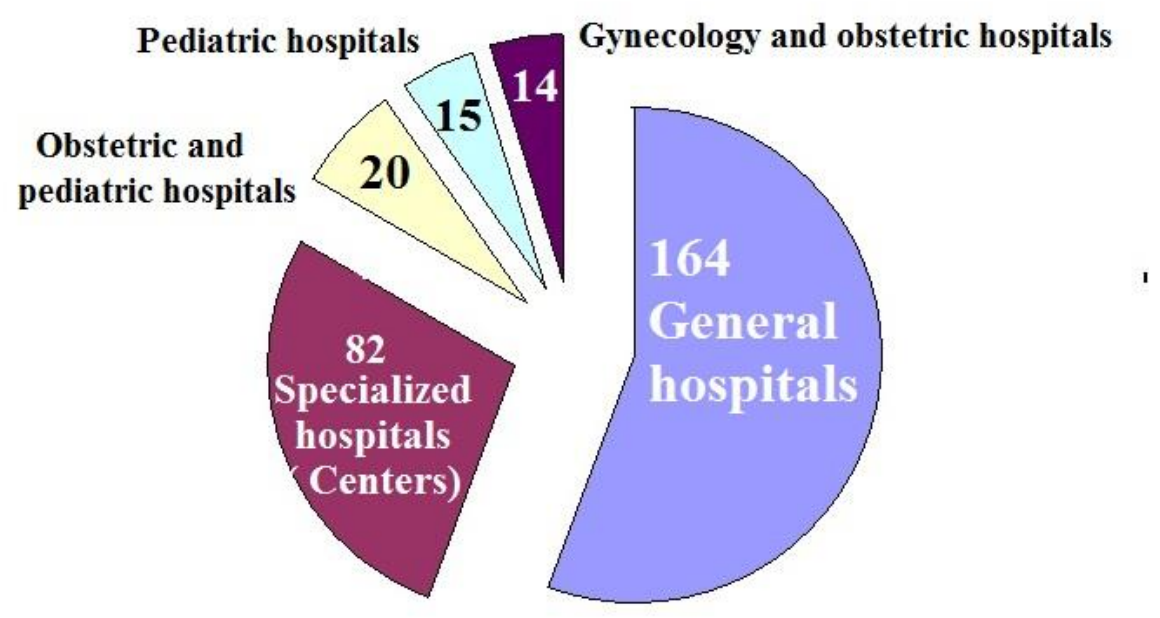

Figure 6: The main types of governmental hospitals in Iraq in 2020.

A total of 2333187 patients were hospitalized in 2020, and the hospitalization rate was estimated at 58 patients per 1000 population, and the hospitalized patients' mortality rate was $26.3 / 1000$ hospitalized patients.

\section{Data about the Workforce in the Iraq Healthcare System}

In 2020, the total workforce in Iraq healthcare system was 346920 (188018 males and 158902 females) including 38865 physicians (20020 males and 18845 females), 14003 dentists (6106 males and 7897 females), 16512 pharmacists (6414 males and 10098 females), 89990 nursing staff (39617 males and 50373 females), 90327 paramedical staff (52363 males and 37964 females), and 13579 laboratory staff (6325 males and 7254 females). It was estimated that there were 9.68 doctors, 3.49 dentists, 4.11 pharmacists, and 22.41 nursing staff for each 10000 of population.

\section{Data Related To Maternal and Child Health}

533620 pregnancies that were considered risky were registered in 2020. Table-4 shows the numbers and percentage of the causes of risky pregnancies.

\begin{tabular}{|c|c|c|}
\hline & Risk & Number/ Percentage \\
\hline 1 & Anemia of pregnancy & $183069(34.3 \%)$ \\
\hline 2 & Previous abortions & $84042(15.7 \%)$ \\
\hline 3 & Previous caesarean section & $77449(14.5 \%)$ \\
\hline 4 & Last delivery less than 2 years & $60906(11.4 \%)$ \\
\hline 5 & Pregnant under 18 years & $42039(7.9 \%)$ \\
\hline 6 & Four births and more & $40826(7.7 \%)$ \\
\hline
\end{tabular}




\begin{tabular}{|c|c|c|}
\hline 7 & Previous stillbirth & $16515(3.1 \%)$ \\
\hline 8 & Blood group incompatibility & $14509(2.7 \%)$ \\
\hline 9 & Hypertension & $9340(1.8 \%)$ \\
\hline 10 & diabetes in pregnancy & $4925(0.9 \%)$ \\
\hline & Total & $\mathbf{5 3 3 6 2 0 ( \mathbf { 1 0 0 } \% )}$ \\
\hline
\end{tabular}

Table 4: The numbers and percentage of the causes of risky pregnancies

The total number of birth that occurred during the year 2020 was 1019277

(520376 males and 498901) births and 99.3\% of them were live births.

$37 \%$ of infants under six month were exclusively beast fed, $22 \%$ had breast feeding with fluids, $18 \%$ had artificial feeding, and $24 \%$ had mixed feeding.

Congenital malformations including chromosomal abnormalities accounted for $10.9 \%$ of stillbirths in 2020, while intrauterine hypoxia accounted for $1.2 \%$ and complications of prematurity, postmaturity, and intrauterine growth retardation accounted for $1.2 \%$

The crude birth rate was 25.8 / 1000 population. $84 \%$ of births occurred in medical facilities. $90.2 \%$ of births were attended by skilled personnel, and $38.6 \%$ of the babies were delivered by a caesarean section.

$7.7 \%$ births that occurred during the year 2020 during 2020 were less than 2.5 kilograms.

During the year, 2020, 18684 perinatal deaths (10544 males and 8140 females) were reported and the perinatal mortality rate was $18.3 / 1000$ total births.

3129 births occurred in 2020 had congenital malformations which occurred in $3.1 / 1000$ live births. Table-5 shows the percentage of the most common congenital malformations registered by health authorities during the year 2020 which accounted for $63.51 \%$ of all congenital malformations.

\begin{tabular}{|l|l|c|}
\hline \multicolumn{1}{|c|}{ Condition } & $\mathbf{2 0 2 0}$ \\
\hline $\mathbf{1}$ & Congenital malformations of the heart and circulatory system & $24.27 \%$ \\
\hline $\mathbf{2}$ & Congenital hydrocephalus & $7.85 \%$ \\
\hline $\mathbf{3}$ & Congenital malformations of the gastrointestinal tract & $5.96 \%$ \\
\hline $\mathbf{4}$ & Anencephaly and similar malformations & $4.48 \%$ \\
\hline $\mathbf{5}$ & Congenital malformations of the brain and spinal cord & $4.48 \%$ \\
\hline $\mathbf{6}$ & Reduction defects of the lower limbs & $4.37 \%$ \\
\hline $\mathbf{7}$ & Down syndrome & $3.41 \%$ \\
\hline $\mathbf{8}$ & Reduction defects of the upper limbs & $3.2 \%$ \\
\hline $\mathbf{9}$ & Spina bifida & $2.79 \%$ \\
\hline $\mathbf{1 0}$ & Chromosomal abnormalities & $2.72 \%$ \\
\hline & Percentage of the most common ten congenital malformations & $\mathbf{6 3 . 5 1 \%}$ \\
\hline
\end{tabular}

Table 5: The percentage of the main types of congenital malformations.

25298 deaths of children under the age of 15 years occurred during the year 2020 in Iraq (Excluding the 3 Kurdish provinces in the North of Iraq) and accounted for $16 \%$ of all deaths. 13861 neonatal deaths in Iraq including the 3 Kurdish provinces (8114 males and 5747) were reported and the neonatal mortality rate was 13.7 /1000 live births. Table- 6 shows the percentage of the main causes of neonatal death (Excluding the 3 Kurdish provinces in the North of Iraq).

\begin{tabular}{|c|l|c|}
\hline & \multicolumn{1}{|c|}{ Condition } & $\mathbf{2 0 2 0}$ \\
\hline $\mathbf{1}$ & Pulmonary and cardiovascular diseases including pneumonias & $25.8 \%$ \\
\hline $\mathbf{2}$ & Congenital malformations and Chromosomal abnormalities & $\%$ \\
\hline $\mathbf{3}$ & Congenital and neonatal infections including bacterial diseases & $0.5 \%$ \\
\hline $\mathbf{4}$ & Hemorrhagic and hematological disorders of fetus and newborn & $\%$ \\
\hline
\end{tabular}

Table 6: Percentage of the most common causes of neonatal death (Excluding the 3 Kurdish provinces in the North of Iraq).

18684 deaths (10711 males and 7973 ) occurred in infants under the age of one year in Iraq including the 3 Kurdish provinces, and the infant mortality rate (Deaths during the first year of life) was 18.5 / 1000 live births. Table-7 shows the percentage of the main causes of infant death in Iraq (Excluding the 3 Kurdish provinces in the North of Iraq).

Under 5 year mortality was 23.6 per 100000 live births.

\begin{tabular}{|c|l|c|}
\hline & \multicolumn{1}{|c|}{ Condition } & $\mathbf{1}$ \\
\hline $\mathbf{1}$ & Pulmonary and cardiovascular diseases including pneumonias & $39.7 \%$ \\
\hline $\mathbf{2}$ & Congenital malformations and Chromosomal abnormalities & $14.4 \%$ \\
\hline $\mathbf{3}$ & Congenital and neonatal infections including bacterial diseases & $9.7 \%$ \\
\hline $\mathbf{4}$ & Renal failure & $4.3 \%$ \\
\hline $\mathbf{5}$ & Gastroenteritis & $1.4 \%$ \\
\hline $\mathbf{6}$ & Disorders of the nervous system & $1.2 \%$ \\
\hline & Percentage of the main causes of infant death & $\mathbf{7 0 . 7} \%$ \\
\hline
\end{tabular}

Table 7: Percentage of the main causes of infant death in Iraq (Excluding the 3 Kurdish provinces in the North of Iraq). 
3523 deaths (1974 males and 1549 females) occurred in children aged one to four years during the year 2020 in Iraq (Excluding the 3 Kurdish provinces in the North of Iraq), and accounted for $2.2 \%$ of all deaths.

7390 cases of respiratory diseases were registered in children under five years in healthcare centers in Iraq (Excluding the 3 Kurdish provinces in the North of Iraq) including $0.65 \%$ with pneumonia. Cases of pneumonia in children under five years in hospitals accounted for $10.3 \%$ of the hospitalized under five years children in 2020.

23829 deaths (13627 males and 10202 females) occurred in children less than five years, and the under 5-year mortality rate was 23.6/ 1000 live births. Table- 8 shows the percentage of the main causes of death in under five-year children.

\begin{tabular}{|l|l|c|}
\hline & \multicolumn{1}{|c|}{ Condition } & \multicolumn{1}{|c|}{$\mathbf{1 0 2 0}$} \\
\hline $\mathbf{1}$ & Pulmonary and cardiovascular diseases including pneumonias & $30.5 \%$ \\
\hline $\mathbf{2}$ & Congenital malformations and Chromosomal abnormalities & $11.9 \%$ \\
\hline $\mathbf{3}$ & Congenital and neonatal infections including bacterial diseases & $9.6 \%$ \\
\hline $\mathbf{4}$ & Prematurity, postmaturity, and intrauterine growth retardation & $4.6 \%$ \\
\hline $\mathbf{5}$ & $\begin{array}{l}\text { Disorders of the nervous system including cerebral palsy and other } \\
\text { paralytic conditions }\end{array}$ & $2.4 \%$ \\
\hline $\mathbf{6}$ & Renal failure & $1.4 \%$ \\
\hline & Percentage of the main causes of under five-year death & $\mathbf{6 0 . 4} \%$ \\
\hline
\end{tabular}

Table 8: Percentage of the main causes of under five-year death in Iraq (Excluding the 3 Kurdish provinces in the North of Iraq).

2163 deaths (1264 males and 899 females) occurred in children aged 5 to 9 years 2020 in Iraq (Excluding the 3 Kurdish provinces in the North of Iraq) and accounted for $1.4 \%$ of all deaths.

1907 deaths (1100 males and 807) occurred in children aged 10 to 14 years 2020 in Iraq (Excluding the 3 Kurdish provinces in the North of Iraq) and accounted for $1.2 \%$ of all deaths.
In addition, 2690 deaths (1702 males and 988 females) occurred in the age group of 15-19 years 2020 in Iraq (Excluding the 3 Kurdish provinces in the North of Iraq) and accounted for $1.7 \%$ of all deaths. Table-9 shows the percentage of the most common causes of death in the age group 10 to 19 years in Iraq (Excluding the 3 Kurdish provinces in the North of Iraq).

\begin{tabular}{|l|l|c|}
\hline & \multicolumn{1}{|c|}{ Condition } & Percentage \\
\hline $\mathbf{1}$ & Accidents & $13.6 \%$ \\
\hline $\mathbf{2}$ & Renal failure & $11.1 \%$ \\
\hline $\mathbf{3}$ & Non- ischemic heart diseases & $8.1 \%$ \\
\hline $\mathbf{4}$ & Cerebral palsy \& other paralytic syndromes & $8 \%$ \\
\hline $\mathbf{5}$ & Lymphoid and hematopoietic malignancies & $5.4 \%$ \\
\hline $\mathbf{6}$ & Influenza and pneumonias & $4.8 \%$ \\
\hline $\mathbf{7}$ & Cerebrovascular diseases & $4.2 \%$ \\
\hline $\mathbf{8}$ & Bacterial diseases & $3.7 \%$ \\
\hline $\mathbf{9}$ & Ischemic heart diseases & $3.2 \%$ \\
\hline $\mathbf{1 0}$ & Other respiratory disorders & $2.4 \%$ \\
\hline & Percentage of the most common causes & $\mathbf{6 4 . 5} \%$ \\
\hline
\end{tabular}

Table 9: The percentage of the most common causes of death in the age group 10 to 19 years in Iraq (Excluding the 3 Kurdish provinces in the North of Iraq).

A total of 346 maternal deaths were registered in 2020, and the maternal mortality rate was $34.2 / 100000$ live birth. Covid-19 disease was the third most common direct cause of maternal death (Table-10).
During the year, 2020, there were 49298 registered abortions in Iraq (Excluding the Kurdish provinces in the North) including $42.9 \%$ spontaneous abortion, $28.3 \%$ medical abortion, and 5\% missed abortion.

\begin{tabular}{|l|l|c|}
\hline & Disorder & Percentage \\
\hline $\mathbf{1}$ & Postpartum hemorrhage & $29.6 \%$ \\
\hline $\mathbf{2}$ & Unspecified maternal hypertension & $14.5 \%$ \\
\hline $\mathbf{3}$ & Covid-19 disease & $9.9 \%$ \\
\hline $\mathbf{4}$ & Pulmonary embolism & $9.6 \%$ \\
\hline $\mathbf{5}$ & Uterine rupture & $3.2 \%$ \\
\hline $\mathbf{6}$ & Obstetric embolism & $2.1 \%$ \\
\hline $\mathbf{7}$ & Sepsis & $1.5 \%$ \\
\hline $\mathbf{8}$ & Abortion & $1.6 \%$ \\
\hline $\mathbf{9}$ & Eclampsia & $0.02 \%$ \\
\hline $\mathbf{1 0}$ & Complications of anesthesia & $0.003 \%$ \\
\hline & Ten most common causes of death & $72 \%$ \\
\hline
\end{tabular}

Table 10: The main causes of direct maternal death in Iraq during the year 2020. 


\section{Data about Notifiable Infectious Disease}

Covid-19 disease has emerged as a new notifiable infectious disease in Iraq and throughout the world. However, there were 123102 patients with notifiable infectious diseases other than covid-19 disease registered by the national and local health authorities in Iraq in 2020.

Therefore, the registered cases of covid-19 disease was about 4.8 times more than the number of all notifiable infectious disease registered in Iraq during the year 2020 .

42714 (21432 males and 21282 females) of scabies were registered in Iraq in 2020 [106/4/100.000 population]. 5551 patients were under the age of one year, 5205 were between 1-4 years, 8756 were between 5-9 years, 7533 were between $10-14$ years, 7213 were between $15-19$ years, 5510 were between 20-44 years, 1715 were between $45-64$ years, and 1231 were above 64 years.

12251 (6573 males and 5678 females) cases of chicken pox were registered in Iraq in 2020 [30/100.000 population]. 1878 were under one year of age, 1496 were between 1-4 years, 2123 were between 5-9 years, 2005 were between 10-14 years, 1817 were between $15-19$ years, 1559 were between 20-44 years, 779 were between $45-64$ years, and 594 were above 64 years.

7957 cases of cutaneous leishmaniasis (4417 males and 3540 females) were registered in Iraq in 2020 [19.8/100.000 population]. 463 patients were under the age of one year, 1815 were between $1-4$ years, 1367 were between 5-9 years, 913 were between 10-14 years, 621 were between 1519 years, 2068 were between 20-44 years, 619 were between $45-64$ years, and 91 were above 64 years.

5015 cases (2461 males and 2554 females) of tuberculosis were registered in Iraq in 2020 [12/100.000 population] including 2643 patients (1415 males and 1228 females 0 with pulmonary tuberculosis [7/100.000 population] and 2372 patients (1046 males and 1326 females) with extrapulmonary tuberculosis $[6 / 100.000$ population].

860 cases of mumps (490 males and 370 females) were registered in Iraq in 2020 [2/100.000 population. Only one patient was under one year of age, 163 were between one to years, 277 were between 5 to 9 years, 265 were between 10 to 14 years, 53 were between 15 to 19 years, 77 were between 20 to 44 years, and were 24 above, 2 of them were over 64 years.

There were a total of 1521 cases of infective hepatitis registered in Iraq in 2020.

662 (335 males and 327 females) cases of hepatitis A infection were registered, and the disease occurred in 1.6 individuals of each 100.000 population. Only one patient was under the age of one year, 155 were between the age of 1 to 4 years, 259 were between the age of 5 to 9 years, 125 were between 10-14 years, 51 were between $15-19$ years, 60 were between 20-44 years, and 11 patients were above the age of 44 years including 2 above the age of 64 years.

574 (332 males and 242 females) cases of hepatitis B infection were registered, and the disease occurred in 1.43 individuals of each 100.000 population. Only one patient was under the age of one year, 2 were between the age of 1 to 4 years, 14 were between the age of 5 to 9 years , 12 were between 10-14 years, 21 were between 15-19 years, 342 were between 20-44 years, 133 were between $45-64$ years, and 40 patients were above 64 years.
284 (127 males 157 females) of hepatitis C were registered in Iraq in 2020 [0.7/100.000 population. 4 patient were under the age of one year, 4 were between the age of 1 to 4 years, 16 were between the age of 5 to 9 years, 8 were between 10-14 years, 20 were between $15-19$ years, 111 were between 20-44 years, 87 were between $45-64$ years, and 34 patients were above 64 years

Only one case of hepatitis $\mathrm{E}$ which occurred in a male was registered in Iraq in 2020.

361 cases $(213$ males and 148 females of Acute flaccid paralysis were registered in Iraq in 2020 [0.9/100.000 population. 179 patients were between the age of 1 to 4 years, 136 were between the age of 5 to 9 years, and 46 patients were under the age of one year.

330 (202 males and 128 females) cases of brucellosis were registered in Iraq in 2020 [0.8/100.000 population. 16 were under the age of one year, 26 were between 1-4 years, 21 were between 5-9 years, 24 were between 10-14 years, 18 were between $15-19$ years, 139 were between $20-44$ years, 61 were between 45-64 years, and 25 patients were above 64 years.

298 ( 165 males and 133 females) of typhoid fever measles were registered in Iraq in 2020 [0.7/100.000 population. Two patients were under two years of age, 51 were between 1-4 years, 68 were between 5-9 years, 43 were between 10-14 years, 15 were between 15-19 years, 84 were between 20-44 years, and 35 were between 45-64years.

281 cases (132 males and 149 females) of measles were registered in Iraq in 2020 [0.7/100.000 population. 63 were under one year of age, 95 patients were between 1 to 4 years, 41 patients were between 5 to 9 years, and 21 patients were between 10 to 14 years, 6 patients were between 15 19 years, 50 patients were between 20-44 years, and 5 patients were above 44 years, 4 of them aged more than 64 years.

280 (169 males and 111 females) of all types of meningitis were registered in Iraq in 2020 [0.7/100.000 population.

179 cases of viral meningitis were registered including 71 patients under the age of one year, 64 were between 1-4 years, 19 were between 5-9 year, 11 were between 10-14 years, 2 were between $15-19$ years, 5 were between 20-44 years, and 7 were above 44 years, 3 of them were above 64 years.

88 cases of bacteria meningitis were registered including 45 patients under the age of one year, 21 were between 1-4 years, 6 were between 59 year, 2 were between 10-14 years, 4 were between $15-19$ years, 5 were between 20-44 years, and 5 were above 44 years, 3 of them were above 64 years.

210 (175 males and 35 females) of human immune deficiency infection was registered [5.2 affected individuals of each 100.000 population], and 12 (8 males and 4 females) patients died.

203 cases of food poisoning were registered in 2020 including one patient under the age of one year, 19 were between 1-4 years, 41 were between 5-9 year, 43 were between 10-14 years, 25 were between 15-19 years, 62 were between 20-44 years, and 12 were above 44 years, 2 of them were above 64 years.

76 cases of pertusis ( 38 males and 38 females) were registered in Iraq in 2020 [0.02/10.000 population. 28 patients were under one year of age, 23 patients were between 1 to 4 years, 21 patients were between 1 to 4 years, 2 patients were between 5 to 9 years, and 2 patients were between 10 to 14 years. 
46 cases of kala azar ( 25 males and 21 females) were registered in Iraq in 2020 including 14 patients under the age of one year, 29 were between 1 to 4 years, 2 were between 5 to 9 years, and one patient was between 10 to 14 years.

41 cases of hydatid cyst (10 males and 31 females) including 3 patients between the age of between 5 to 9 years, 5 between 10 to 14 years, 6 between $15-19$ years, 14 between 20-44 years, and 13 were above 44 years including one patient above 64 years.

There were 26 (14 males and 12 females) registered cases of H1N1 influenza, and 5 cases ( 2 males and 3 females) of confirmed H3N2 in 2020 .

Eleven cases of rabies (9 males and 2 females) including 2 patients between the ages of 5-9 years, 5 were between 10-14 years, 2 were between 20-44 years and 2 were above the age of 44 years, one of them was above the age of 64 years.

Ten cases of tetanus were registered including five patients between the age of 5 -9 years, 2 between 10-14 years, three patients were above 19 years including one patient above 44 years, and one patient above 64 years.

Eight cases of toxoplasmosis which occurred in 8 females aged 20 to 44years.
One case of rubella which occurred in a female aged 5-9 years, one case of hemorrhagic fever which occurred in a male, and one case of bacillary dysentery which occurred in a male aged 15-19 years were registered.

Infectious diseases that have to be notified to the health authorities that were not registered during the year 2020 include cholera, poliomyelitis, neonatal tetanus, malaria, bilhariziasis, and diphtheria.

\section{Data about Chronic Disorders and Main Causes of Morbidity and Mortality}

20941 cases of pneumonia (not caused by covid-19 disease) were registered in 2020 including 9203 cases under the age of one year, 6369 were between 1-4 years, 2963 were between 5-9 years, 1567 were between 10-14 years, 552 were between 15-19 years, 200 were between 20-44 years, 71 were between $45-65$ years and 16 were above the age of 64 years.

Acute tonsillitis was the most common cause of outpatient morbidity. Table-11 shows the percentage of the most common cause of outpatient morbidity in Iraq in 2020 (Excluding the three Kurdish Provinces in the North of Iraq).

65909 (5516 males and 60393 females) cases of genital infectious including sexually transmitted diseases were registered in Iraq in 2020 (Table-12).

\begin{tabular}{|l|l|c|}
\hline & \multicolumn{1}{|c|}{ Disorder } & Percentage \\
\hline 1 & Acute tonsillitis & $6.4 \%$ \\
\hline 2 & Acute bronchitis/ bronchiolitis & $5.3 \%$ \\
\hline 3 & Acute pharyngitis & $4.3 \%$ \\
\hline 4 & Urinary system disorders & $3.9 \%$ \\
\hline 5 & Essential (primary) hypertension & $2.8 \%$ \\
\hline 6 & Influenza & $2.7 \%$ \\
\hline 7 & Acute upper respiratory infection & $2.6 \%$ \\
\hline 8 & Infective gastreoeritis & $2.5 \%$ \\
\hline 9 & Diseases of the skin and subcutaneous tissue & $2 \%$ \\
\hline 10 & Insulin dependent diabetes mellitus & $2 \%$ \\
\hline
\end{tabular}

Table 11: The percentage of the most common cause of outpatient morbidity in Iraq in 2020 (Excluding the three Kurdish Provinces in the North of Iraq).

\begin{tabular}{|l|l|c|c|c|}
\hline & \multicolumn{1}{|c|}{ Disease } & Number & Male & Female \\
\hline 1 & Non-gonococcal cervicitis & 20064 & 0 & 20064 \\
\hline 2 & Candidosis & 19760 & 511 & 19249 \\
\hline 3 & Bacterial Vaginosis & 12512 & 0 & 12512 \\
\hline 4 & Trichomoniasis & 4337 & 84 & 4253 \\
\hline 5 & Molluscum contagiosum & 2171 & 978 & 1193 \\
\hline 6 & Genital warts & 1783 & 567 & 1216 \\
\hline 7 & Syphilis & 1510 & 1419 & 91 \\
\hline 8 & Non-gonococcal urethritis & 1314 & 1314 & 0 \\
\hline 9 & Chancroid & 945 & 128 & 817 \\
\hline 10 & Genital herpes & 799 & 567 & 232 \\
\hline 11 & Pubic pediculosis & 253 & 84 & 169 \\
\hline & & $\mathbf{6 5 9 0 9}$ & $\mathbf{5 5 1 6}$ & $\mathbf{6 0 3 9 3}$ \\
\hline
\end{tabular}

Table 12: The numbers and gender of genital infectious including sexually transmitted diseases registered in Iraq in 2020

13237 cases of animal bites were registered in 2020 including 868 cases under the age of one year, 807 were between 1-4 years, 2919 were between 5-9 years, 2798 were between 10-14 years, 2565 were between 15-19 years, 2002 were between 20-44 years, 910 were between 45-65 years and 368 were above the age of 64 years.
Covid-19 disease was the sixth most common cause of hospitalization of patients aged 20 to 24 years in Iraq except the Kurdish provinces in the North of Iraq during the year 2020 accounting for $0.95 \%$ (Table-13). 


\begin{tabular}{|l|l|c|}
\hline & Disorder & Percentage \\
\hline $\mathbf{1}$ & Disorders of the digestive system & $5.8 \%$ \\
\hline $\mathbf{2}$ & Disorders of genitourinary system & $3.0 \%$ \\
\hline $\mathbf{3}$ & Hematological disorders & $2.2 \%$ \\
\hline $\mathbf{4}$ & Injury, poisoning and other external causes & $2 \%$ \\
\hline $\mathbf{5}$ & Disorders of the respiratory system & $1.4 \%$ \\
\hline $\mathbf{6}$ & Covid-19 disease & $0.95 \%$ \\
\hline $\mathbf{7}$ & Specific medical procedures & $0.94 \%$ \\
\hline $\mathbf{8}$ & Disorders of circulatory system & $0.66 \%$ \\
\hline $\mathbf{9}$ & Undiagnosed illnesses & $0.28 \%$ \\
\hline $\mathbf{1 0}$ & Infectious and parasitic diseases & $0.26 \%$ \\
\hline
\end{tabular}

Table 13: The main causes of hospitalization of patients aged 20 to 24 years in Iraq, except the Kurdish provinces in the North of Iraq during the year 2020 .

Ischemic heart disease was the most common non-communicable diseases. Figures 7A and B show the numbers and gender of patients with main non-communicable diseases in Iraq in 2020. During the year 2020, 173928 individuals died in Iraq including 92210
(53\%) individuals died in medical facilities and 81718 (47\%) died out side medical facilities.

The crude death rate during the year 2020 was 4.4 / 1000 of the population.

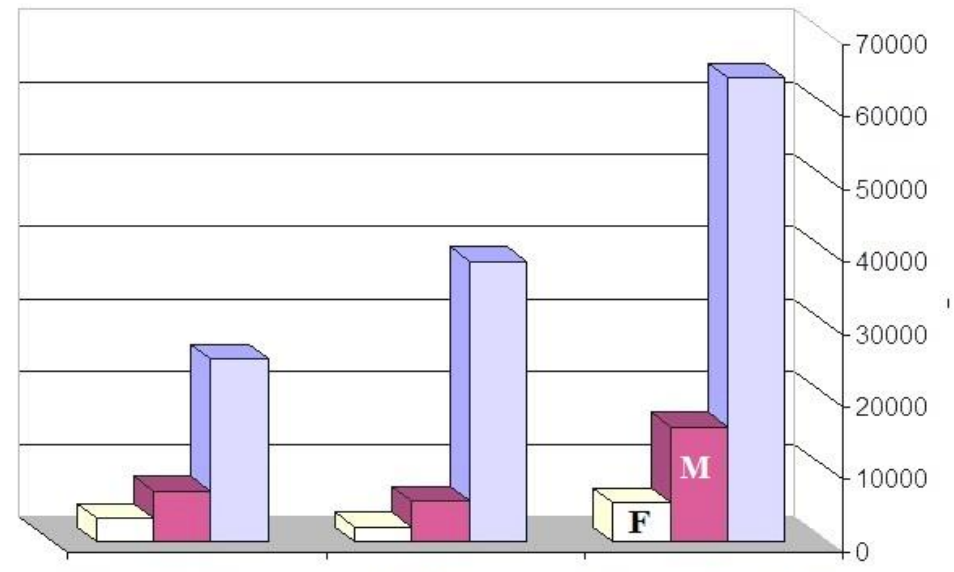

Hypertension Diabetes Ischemic heart disease

Figure 7A: The numbers and gender of patients with main non-communicable diseases in Iraq in 2020.
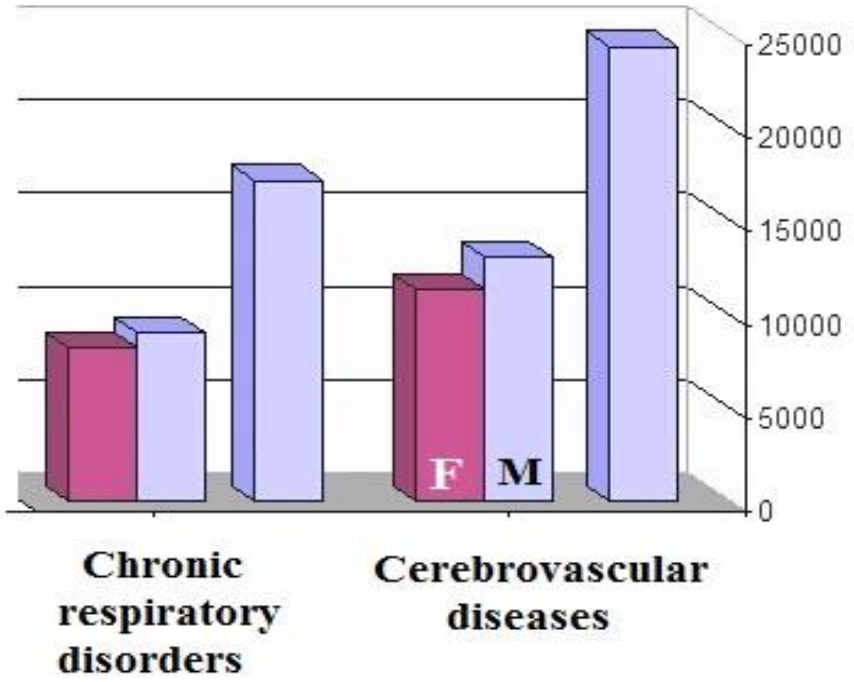

Figure 7B: The numbers and gender of patients with main non-communicable diseases in Iraq in 2020. 
During the year 2020, ten conditions accounted for $64.6 \%$ of the total deaths in Iraq except the Kurdish provinces in the North of Iraq during the year 2020 (Table-14A). Covid-19 disease was also the second most common cause of death in males (Table-14B), but it was the sixth most common cause of death in females (Table-14C).

\begin{tabular}{|l|l|c|}
\hline & Disorder & Percentage \\
\hline $\mathbf{1}$ & Ischemic heart disease & $11.2 \%$ \\
\hline $\mathbf{2}$ & Covid-19 disease & $8.6 \%$ \\
\hline $\mathbf{3}$ & Cerebro-vascular disorders & $8.5 \%$ \\
\hline $\mathbf{4}$ & Hypertensive disease & $8.1 \%$ \\
\hline $\mathbf{5}$ & Non-ischemic, non hypertensive heart disease & $6.3 \%$ \\
\hline $\mathbf{6}$ & Diabetes mellitus & $6 \%$ \\
\hline $\mathbf{7}$ & Cancers & $5.8 \%$ \\
\hline $\mathbf{8}$ & Renal failure & $4.1 \%$ \\
\hline $\mathbf{9}$ & Neonatal cardiopulmonary disorders & $3.7 \%$ \\
\hline $\mathbf{1 0}$ & Road Traffic accidents & $2.3 \%$ \\
\hline
\end{tabular}

Table 14A: The main causes of mortality in Iraq, except the Kurdish provinces in the North of Iraq during the year 2020.

\begin{tabular}{|l|l|c|}
\hline & Disorder & Percentage \\
\hline $\mathbf{1}$ & Ischemic heart disease & $14.1 \%$ \\
\hline $\mathbf{2}$ & Covid-19 disease & $8.8 \%$ \\
\hline $\mathbf{3}$ & Cerebro-vascular disorders & $6.8 \%$ \\
\hline $\mathbf{4}$ & Hypertensive disease & $6.5 \%$ \\
\hline $\mathbf{5}$ & $\begin{array}{l}\text { Non-ischemic, non hypertensive heart } \\
\text { disease }\end{array}$ & $6.1 \%$ \\
\hline $\mathbf{6}$ & Diabetes mellitus & $4.9 \%$ \\
\hline $\mathbf{7}$ & Renal failure & $4.9 \%$ \\
\hline $\mathbf{8}$ & Neonatal cardiopulmonary disorders & $4.8 \%$ \\
\hline $\mathbf{9}$ & Road Traffic accidents & $2.8 \%$ \\
\hline $\mathbf{1 0}$ & Cancers & $2.2 \%$ \\
\hline & Ten most common causes of death & $\mathbf{6 1 . 9} \%$ \\
\hline
\end{tabular}

Table 14B: The main causes of mortality in males in Iraq, except the Kurdish provinces in the North of Iraq during the year 2020.

\begin{tabular}{|l|l|c|}
\hline & Disorder & Percentage \\
\hline $\mathbf{1}$ & Ischemic heart disease & $13.5 \%$ \\
\hline $\mathbf{2}$ & Cerebro-vascular disorders & $10.5 \%$ \\
\hline $\mathbf{3}$ & Hypertensive disease & $9.2 \%$ \\
\hline $\mathbf{4}$ & Cancers & $9.2 \%$ \\
\hline $\mathbf{5}$ & Non-ischemic, non hypertensive heart disease & $7.3 \%$ \\
\hline $\mathbf{6}$ & Covid-19 disease & $6.2 \%$ \\
\hline $\mathbf{7}$ & Renal failure & $6.2 \%$ \\
\hline $\mathbf{8}$ & Diabetes mellitus & $4.2 \%$ \\
\hline $\mathbf{9}$ & Neonatal cardiopulmonary disorders & $3.5 \%$ \\
\hline $\mathbf{1 0}$ & Bacterial diseases & $2 \%$ \\
\hline & Ten most common causes of death & $\mathbf{7 1 . 8} \%$ \\
\hline
\end{tabular}

Table 14C: The main causes of mortality in females in Iraq, except the Kurdish provinces in the North of Iraq during the year 2020.

36873 premature deaths from major non-communicable diseases were registered in individuals aged 30-69 years died (3.6 individuals of each 1000 population).

Forensic medicine deaths accounted for $14.2 \%$ of the total deaths during the year 2020 .

369 fatal suicide cases were registered including 201 females and 168 males (1.1 per 100000 populations).

4505 individuals died from road traffic accidents (11.2 per 100.000 populations).
Deaths caused by unintentional poisoning occurred in 0.19 per 100000 populations

\section{Data about Medical Education and Healthcare Education}

In 2020, there were 31 governmental and 3 private colleges of medicine, 22 governmental and 31 private colleges of dentistry, 19 governmental and 28 private colleges of pharmacy, 20 governmental and 18 private colleges of nursing, 7 governmental and 44 private health technical colleges, 48 governmental and 3 health technical institutes, 8 governmental nursing, 7 midwifery schools (Equivalent to ordinary secondary schools). 


\section{Discussion}

Like most of the world's health systems, in Iraq, the most important factor affected the healthcare system in Iraq in 2020 was the spread of covid-19 disease. The covid-19 pandemic changed the mortality pattern in Iraq as covid-19 disease emerged as the second most common cause of death. Table -15 shows the most common causes of death in Iraq in 2018 and 2019.

\begin{tabular}{|l|l|c|c|}
\hline & Disorder & $\mathbf{2 0 1 8}$ & $\mathbf{2 0 1 9}$ \\
\hline $\mathbf{1}$ & Ischemic heart disease & $12.06 \%$ & $12.03 \%$ \\
\hline $\mathbf{2}$ & Cancer & $9.43 \%$ & $9.33 \%$ \\
\hline $\mathbf{3}$ & Cerebro-vascular disorders & $10.36 \%$ & $8.4 \%$ \\
\hline $\mathbf{4}$ & Hypertensive disease & $6.7 \%$ & $6.8 \%$ \\
\hline $\mathbf{5}$ & Non-ischemic heart disease & $7.37 \%$ & $5.9 \%$ \\
\hline $\mathbf{6}$ & Renal failure & $5.85 \%$ & $5.3 \%$ \\
\hline $\mathbf{7}$ & Road Traffic accidents & $4.57 \%$ & $4.9 \%$ \\
\hline $\mathbf{8}$ & Diabetes mellitus & $4.19 \%$ & $4.8 \%$ \\
\hline $\mathbf{9}$ & Neonatal cardiopulmonary disorders & $3.89 \%$ & $4.1 \%$ \\
\hline $\mathbf{1 0}$ & Sepsis and infective disorders & N/A & $2.6 \%$ \\
\hline
\end{tabular}

Table 15: The most common causes of death in Iraq in 2018 and 2019

Covid-19 disease has emerged as a new notifiable infectious disease in Iraq and throughout the world; therefore, it changed the pattern of notifiable infectious diseases in Iraq.

A total of 718393 cases of notifiable infectious disease including covid19 disease were registered in Iraq in 2020 . Figure- 8 shows the percentage of the main notifiable infectious diseases including covid-19 registered in Iraq in 2020.

The first year of covid-19 pandemic in Iraq was not associated with an important increase in the number of primary healthcare centers (Figure9). However, there was little increase in the number of governmental hospitals (Figure-10).

\section{$\square$ Cutaneous leishmaniasis $1.1 \%$}

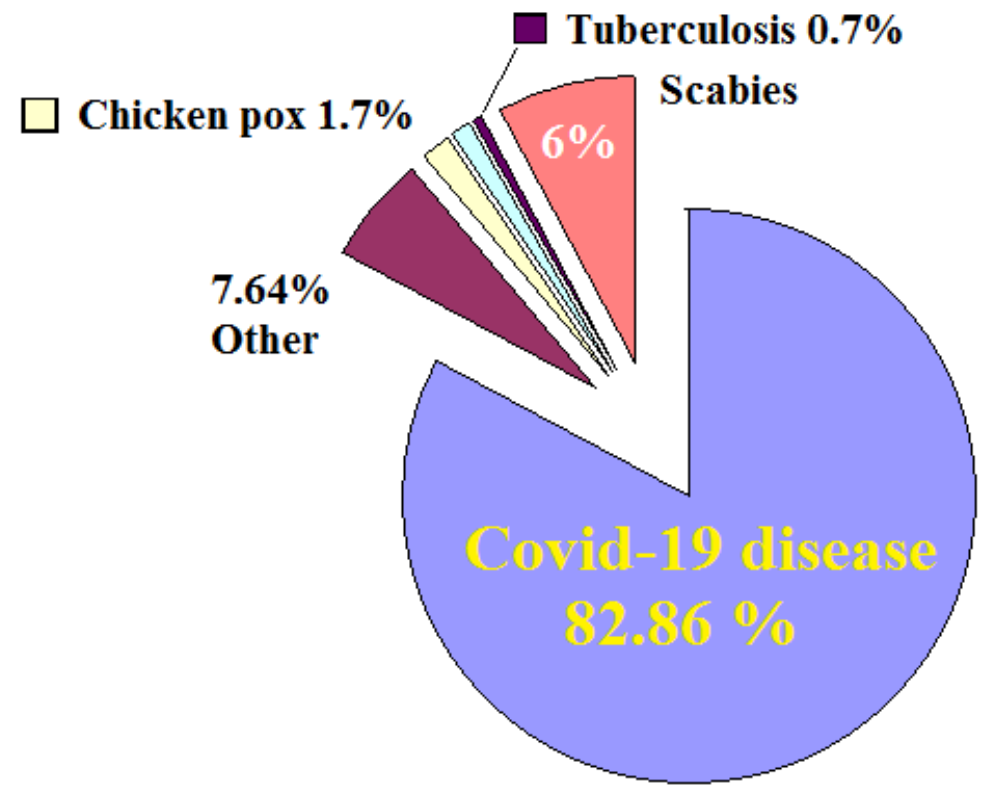

Figure 8: The percentage of the main notifiable infectious diseases including covid-19 registered in Iraq in 2020.

Surprisingly, the bed occupancy rate of governmental hospitals during the first year of the pandemic was lower than the bed occupancy rate during the two years before the pandemic (Figure-11). 


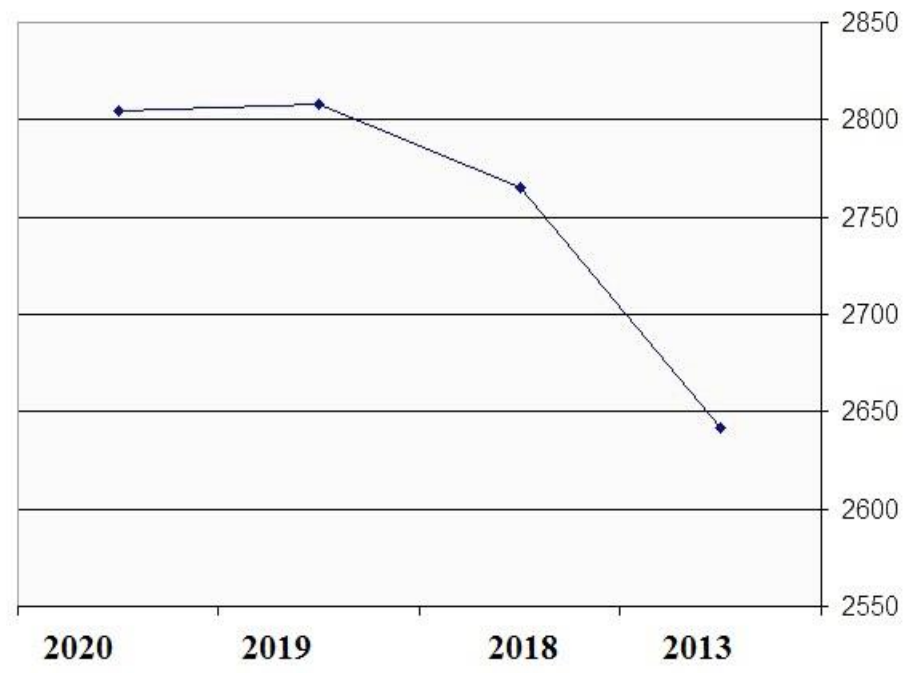

Figure 9: The number of primary healthcare centers in 2013, 2018, 2019, and 2020.

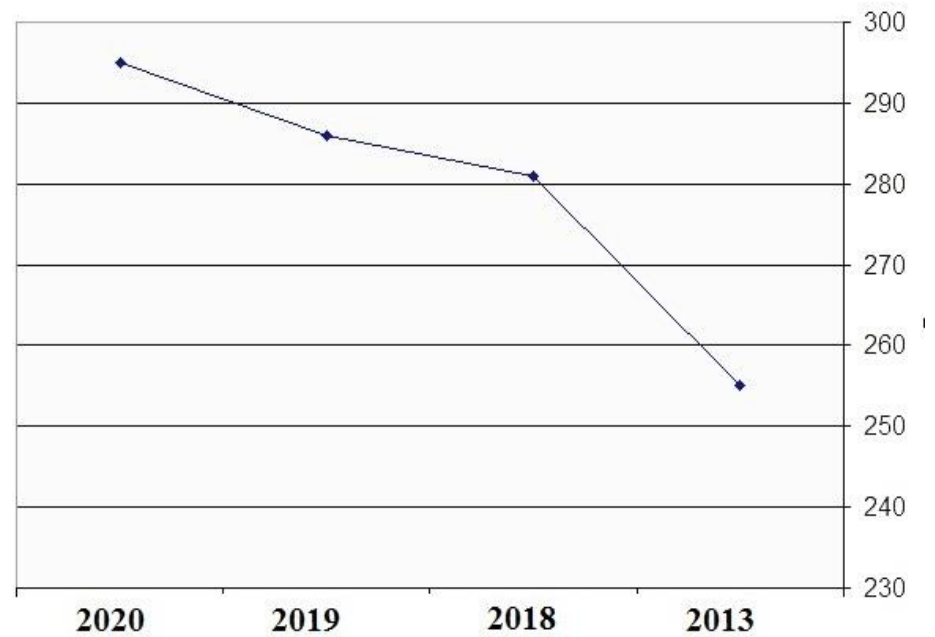

Figure-10: The number of governmental hospitals in 2013, 2018, 2019, and 2020

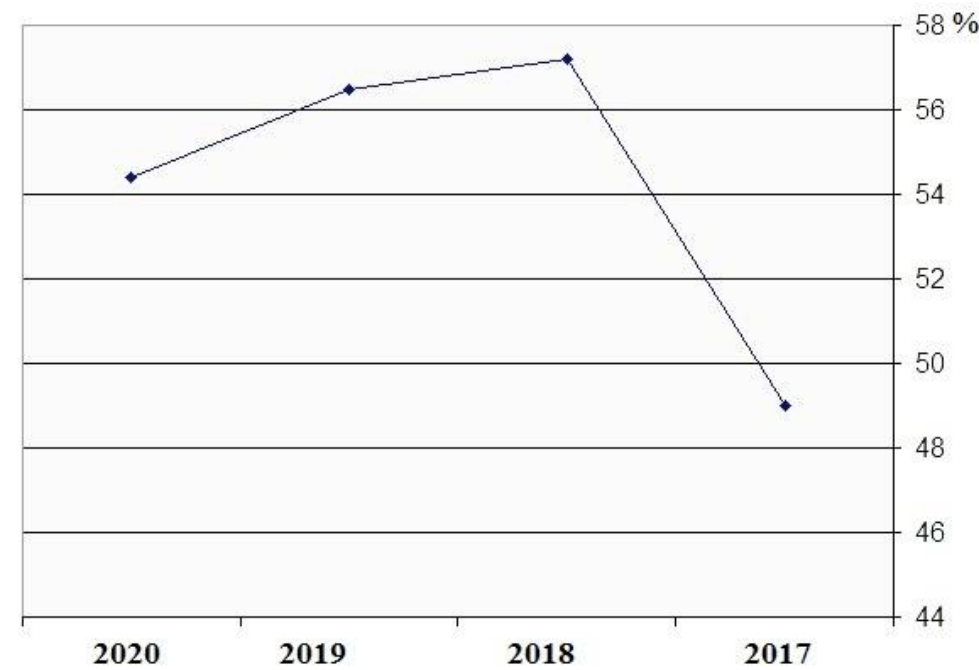

Figure 11: The bed occupancy rate (\%) of governmental hospitals in 2017, 2018, 2019, and 2020. 
The total number of hospitalized patients in 2020 was lower than the previous four years (Figure-12), but the mortality rate per 1000 hospitalized patients was significantly higher in 2020 than the previous four years (Figure-13).

On the first of June 2021, 1,201,352 cases of covid-19 disease were reported by the Iraqi Ministry of Health, and 16375 patients died because of the disease. During, the first week of June, 2021, the death of three Iraqi patients having covid-19 disease complicated by mucormycosis was reported $[11,12,13]$. We are recommending adding mucormycosis to the list of notifiable infectious diseases,

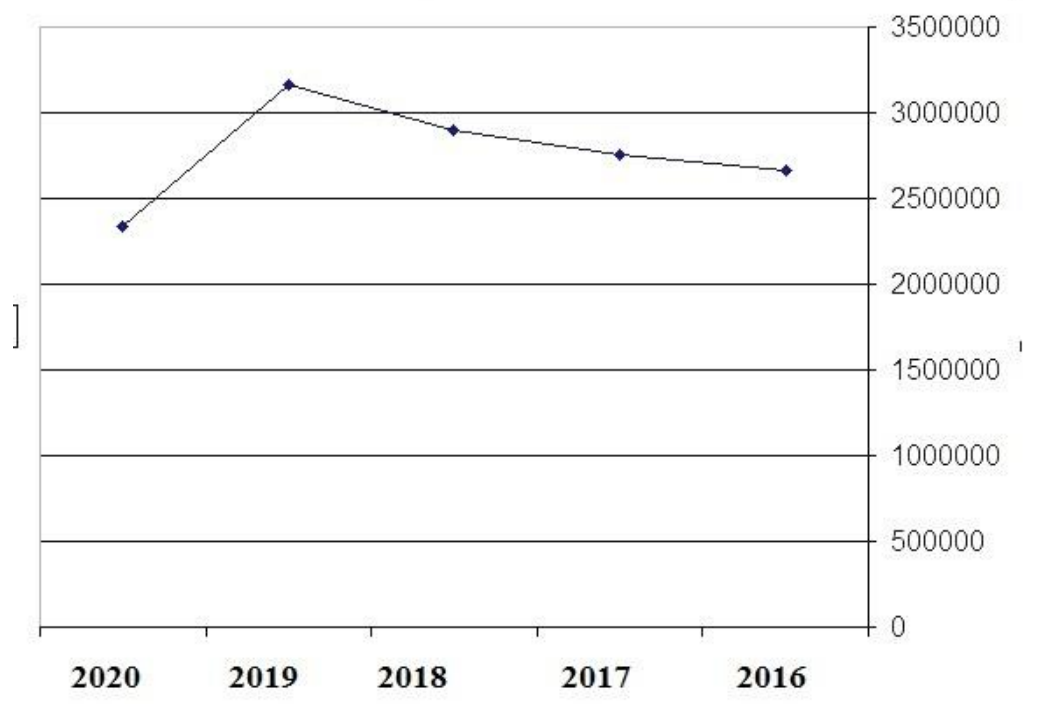

Figure 12: The number of hospitalized patients in 2016, 2017, 2018, 2019, 2020.

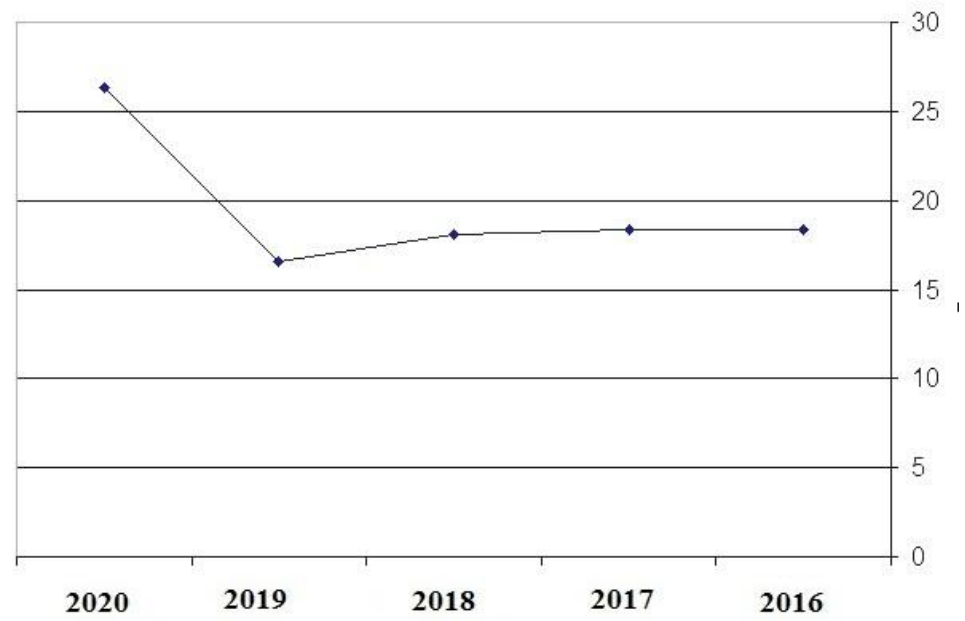

Figure 13: The mortality rate per 1000 hospitalized patients in 2016, 2017, 2018, 2019, 2020.

\section{Conclusion}

Covid-19 disease in Iraq was associated with a significant mortality during the year 2020. It actually changed the previously reported national mortality pattern as covid-19 disease has become the second most common cause of death in Iraq. Contradictory, to the general belief that mortality associated with covid-19 was generally restricted to the older age groups, 117 children under the age of ten years died because of covid19 disease. This number of childhood deaths suggests the need to consider vaccination of the younger age groups and to perform the relevant research. Covid-19 disease has emerged as a new notifiable infectious disease in Iraq and throughout the world; therefore, it changed the pattern of notifiable infectious diseases in Iraq.

\section{Acknowledgement}

Some of the figures published in this book were included in previous author's publications, but the author has their copy right.

\section{Conflict of interests: None.}

\section{References}

1. Al-Mosawi AJ. (2020). Bat-human Coronaviruses: Keys to The Therapeutic Challenge $.1^{\text {st }}$ ed., Baghdad; Iraq Headquarter of Copernicus Scientists International Panel Publishing.

2. Al-Mosawi AJ. (2020). Bat-human coronaviruses: Keys to the therapeutic challenge. $1^{\text {st }}$ ed., Saarbrücken; LAP Lambert Academic Publishing. 
3. Al-Mosawi AJ. (2020). Коронавирусы человека-летучей мыши: ключи к терапевтическому вызову: Evidence-based medicine (Russian Edition) Sciencia Scripts.

4. Al-Mosawi AJ. (2020). Bat-Human Coronaviruses: A Global Health Problem and a Therapeutic Challenge. Journal of Medical Clinical Case Reports. 2(2): 1-3.

5. Al-Mosawi AJ. (2005). Avian influenza A viruses in human: An emerging infectious disease. The New Iraqi Journal of Medicine. 1(3):27-33.

6. Al-Mosawi AJ. (2006). SARS: A new clinical syndrome. The New Iraqi Journal of Medicine. 2(3):25-32.

7. Al-Mosawi AJ. (2020). Iraq Healthcare System before Covid-19 Pandemic. International Journal of Research Studies in Medical and Health Sciences. 5 (12):1-8.
8. Al-Mosawi AJ. (2021). Iraq healthcare system before covid-19 pandemic. Scholar's press.

9. Al-Mosawi AJ. (2021). Gesundheitssystem im Irak vor der Covid19-Pandemie (German edition). Verlag Unser Wissen.

10. Al-Mosawi AJ. (2021). Il sistema sanitario iracheno prima della pandemia di Covid-19 (Italian edition). Edizioni Sapienza.

11. Al-Mosawi AJ. (2021). Mucormycosis: An emerging dangerous complication of Covid-19 disease. Scholars' Press.

12. Al-Mosawi AJ. (2021). Mukormykose: Eine neue gefährliche Komplikation der Covid-19-Krankheit (German edition). Verlag Unser Wissen.

13. Al-Mosawi AJ. (2021). Mucormicosi: Una pericolosa complicazione emergente della malattia di covid-19 (Italian edition). Edizioni Sapienza.
This work is licensed under Creative Commons Attribution 4.0 License

To Submit Your Article Click Here: Submit Manuscript

DOI: $10.31579 / 2768-0487 / 042$
Ready to submit your research? Choose Auctores and benefit from:

* fast, convenient online submission

* rigorous peer review by experienced research in your field

* rapid publication on acceptance

* authors retain copyrights

* unique DOI for all articles

* immediate, unrestricted online access

At Auctores, research is always in progress.

Learn more auctoresonline.org/journals/journal-of-clinical-andlaboratory-research 